\title{
Papers
}

\section{Deletions in the Epstein-Barr virus latent membrane protein-1 oncogene in Hodgkin's disease}

\author{
A Santón, A I Manzanal, E Campo, C Bellas
}

\begin{abstract}
Aims-To analyse the latent membrane protein-1 (LMP-1) gene in a series of patients with Epstein-Barr virus (EBV) positive LMP expressing ordinary and HIV associated Hodgkin's disease to detect possible genetic alterations and particularly the existence of deletions near the $3^{\prime}$ end of the gene.

Methods-Expression of the EBV LMP-1 was assessed using immunohistochemistry in 186 cases of Hodgkin's disease and 31 cases of HIV associated Hodgkin's disease. Genomic DNA was extracted from frozen lymph node biopsy specimens from 25 cases of Hodgkin's disease and 11 of HIV associated Hodgkin's disease, all of whom expressed the LMP-1 protein within diagnostic Hodgkin and Reed-Sternberg (HRS) cells, and amplified by polymerase chain reaction (PCR) using primers specific for the different LMP-1 regions.
\end{abstract}

Results-LMP-1 expression was observed in 106 of 186 Hodgkin's disease cases and in all 31 HIV associated Hodgkin's disease cases. Molecular analysis of the LMP-1 gene showed a high degree of genetic heterogeneity in the carboxy-terminal domain compared with the prototype B95-8 EBV strain, specially in the patients with HIV associated Hodgkin's disease. Variation in the size of the repeated region was found in 17 of 25 Hodgkin's disease and nine of 11 HIV associated Hodgkin's disease cases. Deletions of 30 base pairs near the $3^{\prime}$ end of the gene were detected in all cases of HIV associated Hodgkin's disease and in six Hodgkin's disease. In one case of Hodgkin's disease a larger deletion was observed. In all patients with LMP-1 deletion mutants, $50-90 \%$ of the diagnostic HRS cells expressed the LMP-1 protein. Conclusions-The presence of the 30 base pair deletion in all cases of HIV associated Hodgkin's disease supports previous studies that reported aggressive histological and clinical behaviour in tumours harbouring this deletion. This deletion may prolong the half-life of the protein which would explain the high levels of LMP-1 expressing HRS cells in those cases carrying LMP-1 deletions. That the 30 base pair deletion was present in all of the HIV associated Hodgkin's disease specimens suggests that impairment of immune function is a stringent requirement for the expansion of malignant cells infected by EBV strains containing the deleted LMP-1 gene.

(f Clin Pathol: Mol Pathol 1995;48:M184-M187)

Keywords: Epstein-Barr virus, latent membrane protein-1, Hodgkin's disease, HIV.

Epstein-Barr virus (EBV) is an ubiquitous human herpesvirus associated with several malignancies including Burkitt's lymphoma, particularly in the high incidence areas of tropical Africa, nasopharyngeal carcinoma, lymphoproliferative disorders in immunocompromised patients, and Hodgkin's disease. ${ }^{1}$

EBV has been detected in up to $93 \%$ of Hodgkin's disease cases using the highly sensitive Polymerase Chain Reaction (PCR). ${ }^{2}$ Patients with EBV positive Hodgkin's disease often express latent membrane protein-1 (LMP-1), this expression being restricted to Hodgkin and Reed-Sternberg (HRS) cells. ${ }^{34}$ LMP-1 can transform rodent fibroblasts and render them tumorigenic in nude mice. ${ }^{56}$ In $\mathrm{B}$ cells, LMP-1 induces expression of different activations markers, adhesion molecules, NF$\mathrm{KB}$, and the $b c l-2$ oncogene. ${ }^{7-9}$ Genetic analyses with EBV recombinants indicate that LMP-1 is essential for primary B lymphocyte transformation. ${ }^{10}$

Structurally, LMP-1 can be divided into three domains: a short intracytoplasmic $\mathrm{N}$ terminal domain, six membrane spanning segments and a $C$ terminal region 200 amino acids in length located in the cytoplasm. ${ }^{11} \mathrm{LMP}-1$ is present in patches in the membrane and is associated with the cytoskeleton. ${ }^{12}{ }^{13} \mathrm{LMP}-1$ is characterised biochemically by serine/threonine phosphorylation and rapid turnover because of specific cleavage of the protein at Leucine 242. Cleavage results in release of phosphorylated fragment (p25) into the cytoplasm. ${ }^{14-17}$ EBV recombinants with deletions in any part of the LMP-1 N terminal domain have substantial growth transforming activity for primary B lymphocytes; ${ }^{18}$ however, those lacking the first 44 amino acids of the LMP-1 C terminal domain are incapable of transforming

Pathology, Hospital Ram
y Cajal, Carretera de
Colmenar Km 9, 28034

Accepted for publication

19 April 1995 
primary B lymphocytes. ${ }^{19}$ It has been shown recently that these 44 amino acids interact with a protein related to the tumour necrosis factor receptor associated factors. This interaction links LMP-1 transforming activity to the signaling pathways of the tumour necrosis factor receptors. $^{20}$

The presence of 30 base pair (bp) deletions in the $\mathrm{C}$ terminal end of LMP-1 (amino acids 343 to 352 of the B95-8 strain) in Hodgkin's disease seems to be associated with aggressive disease. ${ }^{2122}$ Therefore, we have analysed the LMP-1 gene in a series of patients with EBV positive ordinary and HIV associated Hodgkin's disease expressing LMP-1 in order to detect possible genetic alterations and particularly the $30 \mathrm{bp}$ deletion.

\section{Methods}

One hundred and eighty six cases of ordinary Hodgkin's disease and 31 cases of Hodgkin's disease associated with HIV infection were selected from several hospitals in Spain. Diagnosis of Hodgkin's disease was performed routinely on $5 \mu \mathrm{m}$ lymph node sections stained with haematoxilin and eosin. The Hodgkin's disease specimens were subclassified according to the Rye modification of the Lukes and Butler classification. ${ }^{23}$ The clinical stage at presentation was established according to the Ann Arbor System. ${ }^{24}$

Fresh frozen material for DNA extraction was available in 25 ordinary Hodgkin's disease cases (two lymphocyte predominant, 14 nodular sclerosis, nine mixed cellularity), and in 11 patients with HIV associated Hodgkin's disease patients (two nodular sclerosis, six mixed cellularity, two lymphocyte depletion, and one not classifiable). All 11 patients with HIV associated Hodgkin's disease were male and intravenous drug misusers. The degree of infiltration by HRS cells in the group of patients for which DNA extraction was possible was as follows: eight of the ordinary Hodgkin's disease cases contained numerous HRS cells $(5 \cdot 25 \%)$ and the other 17 showed a weak infiltration $(<5 \%)$; in the HIV associated Hodgkin's disease cases, three samples were heavily infiltrated $(>25 \%)$, seven contained numerous HRS cells and one showed a weak infiltration.

\section{IMMUNOHISTOCHEMISTRY}

Immunohistochemical analysis was performed on routinely processed paraffin wax sections with the CS1-4 monoclonal antibody (Dako, Glostrup, Denmark) and standard alkaline phosphatase-antialkaline phosphatase methods. Paraffin wax sections were pretreated in a microwave oven to enhance antigen retrieval. LMP-1 expression was restricted to HRS cells.

DNA ISOLATION AND PCR AMPLIFICATION Total genomic DNA was extracted from frozen lymph node biopsy specimens following as described previously. ${ }^{25}$

EBV typing was performed by amplifying DNA from the EBV 3C nuclear antigen
(EBNA-3C). Amplification of type A EBV DNA gave rise to a 153 bp fragment and type B EBV DNAs to a 246 bp product. Primers and PCR conditions are described elsewhere. ${ }^{26}$

The LMP-1 gene was amplified using different primer pairs specific for the $\mathrm{N}$ terminal, transmembrane and $\mathrm{C}$ terminal domains (for detailed information about PCR conditions and primer sequences see ${ }^{27}$ ). Each PCR product $(5 \mu \mathrm{l})$ was electrophoresed on a $6 \%$ polyacrylamide gel for one hour at 150 volts at room temperature to check the amount, specificity, and size of the PCR product. DNA extracted from the B95-8 and AG876 cell lines was used to control for types $A$ and $B$, respectively, EBV. The AG876 LMP-1 gene contains the same $30 \mathrm{bp}$ deletion (amino acids 343 to 352 of the B95-8 sequence) reported in some EBV positive Hodgkin's tumours. ${ }^{2122829}$

\section{Results}

\section{IMMUNOHISTOCHEMISTRY}

The LMP-1 protein was detected within HRS cells in $106(57 \%)$ of 186 cases of ordinary Hodgkin's disease. In all 31 cases of HIV associated Hodgkin's disease HRS cells exhibited a strong, well defined signal for LMP-1: 50$90 \%$ of HRS cells were positive in each case. This extensive expression of LMP-1 in tumour cells in patients with HIV associated Hodgkin's disease has been reported previously. ${ }^{30}$

\section{ANALYSIS OF LMP-1 GENE}

Amplification of the DNA region coding for the $\mathrm{N}$ terminal and the three transmembrane domains was unsuccessful in six of 25 patients with ordinary Hodgkin's disease and in one of 11 cases of HIV associated Hodgkin's disease. Amplification products of the expected size were detected in the remaining cases. Lack of successful amplification was probably because of polymorphisms or deletions at primer region 1 ( N terminal region of LMP-1).

Analysis of the last intracytoplasmic region of LMP-1 was of particular interest. Amplification of the region containing the $33 \mathrm{bp}$ repeat element displayed considerable variation in the size of the PCR product among different samples: 15 of 25 cases of ordinary Hodgkin's disease and six of 11 cases of HIV associated Hodgkin's disease had longer amplification products than expected, whereas shorter products were obtained in two ordinary and three HIV associated Hodgkin's disease cases. The remaining samples gave rise to specific PCR products (fig 1). In each patient a single band was present indicating the presence of clonal EBV DNA. ${ }^{28}$

When the last intracytoplasmic portion was amplified no product was found in four of 25 cases of ordinary Hodgkin's disease. In the remaining 21 cases a product of $286 \mathrm{bp}$ resulting from the presence of the $30 \mathrm{bp}$ deletion was obtained in six $(28.6 \%)$ cases. In patient HD66 a smaller PCR product was obtained, indicating a longer delection (fig 2). Interestingly, in the seven patients with ordinary Hodgkin's disease harbouring the LMP-1 de- 
Table 1 Clinical findings in patients with ordinary Hodgkin's disease carrying deletions in the $C$ terminal region of the LMP-1 gene

\begin{tabular}{|c|c|c|c|c|c|c|}
\hline Case No. & Sex/age (years) & Stage & Type & $\%$ HRS cells & EBV type & Current status \\
\hline $\begin{array}{r}14 \\
54 \\
66 \\
133 \\
178 \\
179 \\
182\end{array}$ & $\begin{array}{l}M / 5 \\
M / 50 \\
F / 56 \\
M / 43 \\
M / 22 \\
M / 71 \\
M / 30\end{array}$ & $\begin{array}{l}\text { I } \cdot \mathrm{A} \\
\text { III } \cdot \mathrm{B} \\
\text { III } \cdot \mathrm{B} \\
\text { II } \cdot \mathrm{B} \\
\text { III } \cdot \mathrm{B} \\
\text { III } \cdot \mathrm{B} \\
\text { II } \cdot \mathrm{A}\end{array}$ & $\begin{array}{l}\text { NS-I } \\
\text { MC } \\
\text { MC } \\
\text { MC } \\
\text { MC } \\
\text { NS } \\
\text { NS-I }\end{array}$ & $\begin{array}{l}<5 \\
5-25 \\
5-25 \\
<5 \\
5-25 \\
<5 \\
<5\end{array}$ & $\begin{array}{l}\text { B } \\
\text { A } \\
\text { A } \\
\text { A } \\
\text { A } \\
\text { A } \\
\text { B }\end{array}$ & $\begin{array}{l}\text { Alive } \\
\text { Relapse with LCAL } \\
\text { Died } \\
\text { Died } \\
\text { Alive } \\
\text { Died } \\
\text { Alive }\end{array}$ \\
\hline
\end{tabular}

$\mathrm{MC}=$ mixed cellularity; $\mathrm{NS}=$ nodular sclerosis; $\mathrm{LCAL}=$ large cell anaplastic lymphoma. Case 66 had a deletion more than $30 \mathrm{bp}$ long.

Table 2 Clinical findings in patients with HIV associated Hodgkin's disease

\begin{tabular}{lllllll}
\hline Case No. & Origin & Stage & Type & $\%$ HRS cells & EBV type & Current status \\
\hline 1 & Madrid & IV·B & MC & $<5$ & A & Lost to follow up \\
2 & Madrid & III·B & NS-II & $5-25$ & B & Died \\
3 & Madrid & III·B & NS-II & $5-25$ & A & Died \\
4 & Madrid & IV.B & MC & $<5$ & A & Alive \\
5 & Madrid & IV·B & LD & $>25$ & B & Died \\
6 & Barcelona & III·B & MC & $5-25$ & B & Died \\
7 & Barcelona & IV·B & LD & $>25$ & A & Alive \\
8 & Barcelona & III.B & MC & $5-25$ & A & Lost to follow up \\
9 & Barcelona & IV.B & MC & $5-25$ & B & Lost to follow up \\
10 & Barcelona & III·B & nc & $>25$ & B & Lost to follow up \\
\hline
\end{tabular}

All the patients were male and intravenous drug misusers. The $30 \mathrm{bp}$ deletion was present in all patients. $\mathrm{MC}=$ mixed cellularity; $\mathrm{NS}=$ nodular sclerosis; $\mathrm{LD}=$ lymphocyte depletion; $\mathrm{nc}=$ not classifiable.

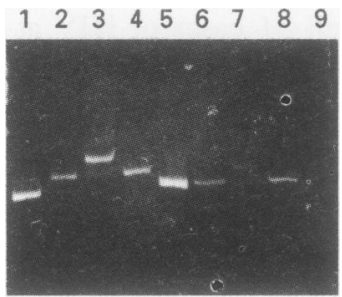

Figure 1 Variation in the size of the $L M P-1$ region containing the repeat element. PCR was used to extracted from fresh, frozen tissue samples. PCR products were separated by electrophoresis on $6 \%$ polyacrylamide, ethidium bromide stained gels. Lanes 1 to 4 , cases $1,2,3$, and 4 (HIV associated

Hodgkin's disease); lane 5, B95-8; lane 6, case 5 (HIV associated Hodgkin's disease); lane 7, case 54 (Hodgkin's disease); lane 8 , case 66 (Hodgkin's disease); lane 9, PCR reaction without DNA. amplify genomic DNA

letion mutants immunohistochemical analysis revealed strong labelling, with $50-90 \%$ of HRS cells exhibiting a positive reaction. In the HIV associated Hodgkin's disease group, amplification was unsuccessful in one case and the remaining 10 cases carried the $30 \mathrm{bp}$ deletion (fig 2). Clinical findings in patients carrying LMP-1 deletions are presented in tables 1 and 2.

\section{EBNA-3C TYPING}

In the group of patients carrying LMP-1 deletions, five of seven cases of ordinary Hodgkin's disease and five of 10 cases of HIV associated Hodgkin's disease gave rise to a $153 \mathrm{bp}$ product from the type A EBNA-3C gene; a 246 bp fragment from type B EBNA$3 \mathrm{C}$ was amplified in the remaining two cases of ordinary Hodgkin's disease and five of HIV associated Hodgkin's disease (tables 1 and 2).

\section{Discussion}

Analysis of the LMP-1 gene in EBV positive Hodgkin's tumours has revealed existence of

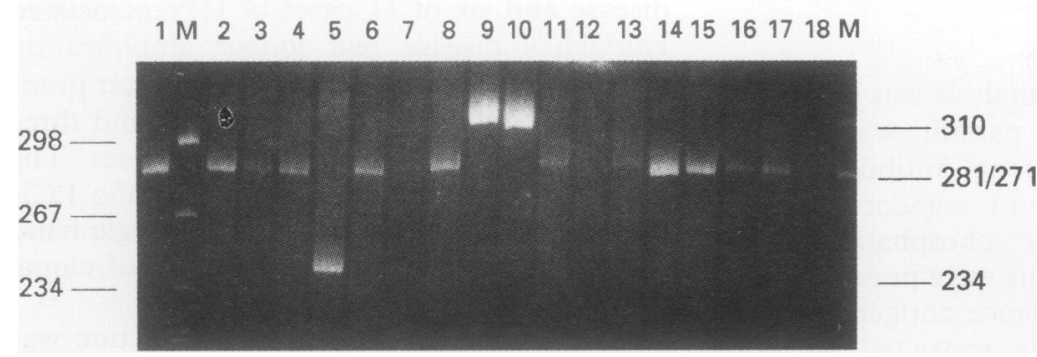

Figure 2 Detection of the $30 \mathrm{bp}$ deletion at the $C$ terminal region of the LMP-1 gene. In isolates containing a deletion between amino acids 343 and 352 a 286 base pair band was detected. In isolates containing these amino acids a $316 \mathrm{bp}$ fragment was detected. The AG876 cell line was used to control for the presence of the $30 \mathrm{bp}$ deletion. Lane 1 , AG876; lanes 2 to 4, cases 1, 2, and 3 (HIV associated Hodgkin's disease); lanes 5 to 7, cases 66, 133 and 178 (Hodgkin's disease); lane 8, case 4 (HIV associated Hodgkin's disease); lane 9, B95-8; lane 10, case 150 (Hodgkin's disease); lanes 11 to 17, cases 5, $11,6,7,8,9$, and 10 (HIV associated Hodgkin's disease); lane 18, PCR reaction without DNA; M, molecular weight marker. The prototype B95-8 (lane 9) and case 150 (lane 10) gave a 316 bp fragment. Case 66 (lane 5) carried a deletion longer than $30 \mathrm{bp}$ and case 11 (lane 12) did not amplify. deletions near the $\mathrm{C}$ terminal end of the protein, which seem to be associated with aggressive disease. ${ }^{2122}$ These deletions, corresponding to amino acids 343 to 352 of the prototype B95$8 \mathrm{EBV}$ strain, were also detected in the AG876 Burkitt's lymphoma cell line ${ }^{2829}$ and in the tumorigenic nasopharyngeal carcinoma cell line CAO. ${ }^{31}$ The frequency of the $30 \mathrm{bp}$ deletion in the Spanish cases of ordinary Hodgkin's disease $(28 \cdot 6 \%)$ is similar to that reported by Sandvej $e t \mathrm{al}^{22}$ in Danish patients with Hodgkin's disease. It is of interest that in this study this deletion was found in all cases of HIV associated Hodgkin's disease. Moreover, we found a statistically significant difference $(p<0.001)$ in the percentage of cases of HIV associated Hodgkin's disease with deletions in the EBV LMP-1 oncogene compared with HD occurring in immunocompetent subjects.

No association has been found between the presence of these deletions and the EBV subtype. In the present study deletions were detected more frequently in type $\mathrm{A}$ isolates because most of the cases of ordinary Hodgkin's disease belonged to this EBV subtype. However, type B EBV is found more frequently in HIV associated Hodgkin's disease $(50 \%$ of cases). The association between type $\mathrm{B}$ disease and compromised immunity has been described elsewhere. ${ }^{32}$

The data presented here confirm the previously reported relation between partial deletions at the $C$ terminal region of the LMP-1 gene and aggressive behaviour in Hodgkin's disease: most of our patients carrying LMP-1 deletions presented with advanced clinical disease at diagnosis, belonged to unfavorable histological subtypes, and contained numerous (5-25\%) HRS cells or were heavily infiltrated ( $>25 \%$ in three cases of HIV associated Hodgkin's disease cases). This features of aggressiveness are greater in the cases of HIV associated Hodgkin's disease (table 2). It is well known that Hodgkin's disease is more aggressive, with a poor response to therapy and 
bad prognosis in patients with HIV infection compared with that in HIV negative patients. $^{3334}$

Transformation assays with deletion mutants have demonstrated that the sequence between amino acid 334 and 364 is required for rapid protein turnover. ${ }^{35}$ Deletions located in this region may affect the turnover of the LMP-1 protein prolonging its half-life and, therefore, promoting a higher level of cellular expression. This hypothesis may explain the strong, well defined signal obtained on immunohistochemistry in patients carrying the deletion mutants.

Although some authors suggest that forms of LMP-1 containing these deletions lack the immunogenic epitopes present in wild-type LMP-1 and therefore escape HLA restricted cytotoxic $\mathrm{T}$ lymphocytes; ${ }^{36}$ however, we think that these highly expressed forms of LMP-1 conserve their immunogenic properties and that unrestricted growth of malignant cells infected by EBV LMP-1 deletion mutants occurs mainly in immunodeficient patients. This may explain the presence of deletions in all cases of HIV associated Hodgkin's disease together with the high proportion of HRS cells (50-90\%) expressing the protein in patients with LMP-1 deletions. The need for impaired immune function does not preclude the existence of deletions in cases of ordinary Hodgkin's disease. The immunological derangement exhibited by untreated patients with Hodgkin's disease is widely documented. ${ }^{37}$

In conclusion, EBV strains containing partial deletions in the $C$ terminal region of the LMP-1 gene may play an important role in the pathogenesis of HIV associated Hodgkin's disease. Furthermore, these deletions could be related to the more aggressive course of Hodgkin's disease in immunodificient patients. Future efforts should be directed towards elucidating whether EBV strains carrying deletions in the LMP-1 gene are important aetiological agents in the development of lymphoproliferative disorders in immunocompromised patients.

1 Miller G. Epstein-Barr virus. Biology, pathogenesis, and medical aspects. In: Fields BN, Knipe DM, eds. Virology. 2nd edn. New York: Raven Press, 1990:1921-51.

2 Samoszuk M, Ravel J. Frequent detection of Epstein-Barr viral deoxyribonucleic acid and absence of Cytomegalovirus deoxyribonucleic acid in Hodgkin's disease megalovirus deoxyribonucleic acid in Hodgkin's disease and acquired immunodeficiency syndrom

3 Herbst H, Dallenbach F, Hummel M, Niedobitek G, Pileri $\mathrm{S}$, Müller-Lantzsch N, et al. Epstein-Barr virus latent membrane protein expression in Hodgkin and Reed-Sternberg cells. Proc Natl Acad Sci USA 1991;88:4766-70.

4 Pallesen G, Hamilton-Dutoit SJ, Rowe M, Young LS. Expression of Epstein-Barr virus latent gene products in
tumour cells of Hodgkin's disease. Lancet 1991;337:320-2.

5 Baichwal VR, Sugden B. Transformation of Balb 3T3 cells by the BNLF-1 gene of Epstein-Barr virus. Oncogene by the BNLF-1

6 Wang D, Liebowitz D, Kieff E. An EBV membrane protein expressed in immortalized lymphocytes transforms established rodent cells. Cell 1985;1985;43:831-40.

7 Wang D, Liebowitz D, Wang F, Gregory C, Rickinson $A$, Larson $R$, et al. Epstein-Barr virus latent infection membrane protein alters the human B-lymphocyte phenotype: deletion of the amino terminus abolishes activity. $\mathcal{f}$ Vimel 1988;62:4173-84.

8 Hammarskjöld M-L, Simurda MC. Epstein-Barr virus latent membrane protein transactivates the human immunodeficiency virus type 1 long terminal repeat through induction of NF-kB activity. $\mathcal{F}$ Virol 1992;66:6496-501.

9 Henderson S, Rowe M, Gregory C, Croom-Carter D, Wang $\mathrm{F}$, Longnecker $\mathrm{R}$, et al. Induction of bcl-2 expression by Epstein-Barr virus latent membrane protein 1 protects infected B-cells from programmed cell death. Cell 1991; 65:1107-15.
10 Kaye KM, Izumi KM, Kieff E. Epstein-Barr virus latent membrane protein 1 is essential for B-lymphocyte growth transformation. Proc Natl Acad Sci USA 1993;90:9150-4.

11 Fennewald S, van Santen V, Kieff E. Nucleotide sequence of an m-RNA transcribed in latent growth-transforming virus infection indicates that it may encode a membrane protein. F Virol 1984;51:411-19.

12 Liebowitz D, Wang D, Kieff E. Orientation and patching of the latent infection membrane protein encoded by of the latent infection membrane protein
Epstein-Barr virus. $\mathcal{F}$ Virol 1986;58:233-7.

13 Martin J, Sugden B. Transformation by the oncogenic latent membrane protein correlates with its rapid turnover, membrane localization, and cytoskeletal association. F Virol 1991;65:3246-58.

14 Mann KP, Thorley-Lawson DA. Posttranslational processing of the Epstein-Barr virus-encoded p63/LMP protein. $\mathcal{F}$ Virol 1987;61:2100-8.

15 Baichwal VR, Sugden B. Postranslational processing of an Epstein-Barr virus-encoded membrane protein expressed in cells transformed by Epstein-Barr virus. $\mathcal{F}$ Virol 1987; 61:866-75.

16 Moorthy R, Thorley-Lawson DA. Processing of the EpsteinBarr virus-encoded latent membrane protein p63/LMP. 7 Virol 1990;64:829-37.

17 Moorthy RK, Thorley-Lawson DA. Biochemical, genetic, and functional analysis of the phosphorylation sites on the Epstein-Barr virus-encoded oncogenic latent membrane protein LMP-1. F Virol 1993;67:2637-45.

18 Izumi KM, Kaye KM, Kieff E. Epstein-Barr virus recombinant molecular genetic analysis of the LMP-1 aminoterminal cytoplasmic domain reveals a probable structural role, with no component essential for primary B-lymphocyte growth transformation. $f$ Virol 1994;68: 4369-76.

19 Kaye KM, Izumi KM, Mosialos G, Kieff E. The EpsteinBarr virus LMP-1 cytoplasmic carboxy terminal is essential for B-lymphocyte transformation; fibroblast cocultivation for B-lymphocyte transformation; fibroblast cocultivation complements a critical function

20 Mosialos G, Birkenbach M, Yalamanchili R, van Arsdale T, Ware C, Kieff E. The Epstein-Barr virus transforming protein LMP-1 engages signaling proteins for the tumor necrosis factor receptor family. Cell 1995;80:389-99.

21 Knecht H, Bachmann E, Brousset P, Sandvej K, Nadal D, Bachmann F, et al. Deletions within the LMP-1 oncogene of Epstein-Barr virus are clustered in Hodgkin's disease and identical to those observed in nasopharyngeal carcinoma. Blood 1993;82:2937-42.

22 Sandvej K, Peh S-C, Andresen BS, Pallesen G. Identification of potential hot spots in the carboxy-terminal part of the Epstein-Barr virus (EBV) BNLF-1 gene in part of the Epstein-Barr virus (EBV) BNLF-1 gene in
both malignant and benign EBV-associated diseases: high frequency of a 30-bp deletion in Malaysian and Danish peripheral T-cell lymphomas. Blood 1994;84:4053-60.

23 Lukes RJ, Butler JJ. The pathology and nomenclature of Hodgkin's disease. Cancer Res 1966;26:1063-83.

24 Carbone PP, Kaplan HS, Musshoff K, Smithiers DW, Tubiana M. Report of the committee on Hodgkin's disease staging. Cancer Res 1971;31:1860-1.

25 Sambrook J, Fritsch EF, Maniatis T. Molecular cloning. $A$ laboratory manual. 2nd edn. Cold Spring Harbor: Cold Spring Harbor Laboratory Press, 1989.

26 Sample J, Young L, Martin B, Chatman T, Kieff E, Rickinson A, et al. Epstein-Barr virus types 1 and 2 differ in their EBNA-3A, EBNA-3B, and EBNA-3C genes. $\mathcal{F}$ Virol 1990;64:4084-92.

27 Knecht H, Bachmann E, Joske DJL, Sahli R, Emery-Goodman A, Casanova JL, et al. Molecular analysis of the LMP (latent membrane protein) oncogene in Hodgkin's disease. Leukemia 1993;7:580-5.

28 Miller WE, Edwars RH, Walling DM, Raab-Traub N. Sequence variation in the Epstein-Barr virus latent membrane protein 1. F Gen Virol 1994;75:2729-40.

29 Sample J, Kieff ED. Epstein-Barr virus types 1 and 2 have nearly identical LMP-1 transforming genes. $f$ Gen Virol 1994;75:2741-6.

30 Audouin J, Diebold J, Pallesen G. Frequent expression of Epstein-Barr virus latent membrane protein-1 in tumour cells of Hodgkin's disease in HIV-positive patients. $\mathcal{f}$ Pathol 1992;167:381-4.

31 Hu L-F, Zabarovsky ER, Chen F, Cao S-L, Ernberg I, Klein $\mathrm{G}$, et al. Isolation and sequencing of the Epstein-Barr virus BNLF-1 gene (LMP-1) from a Chinese nasopharyngeal carcinoma. f Gen Vinol 1991;72:2399-409.

32 Boyle MJ, Vasak E, Tschuchnigg M, Turner JJ, Sculley T, Penny $R$, et al. Subtypes of Epstein-Barr virus (EBV) in Hodgkin's disease: Association between B-type EBV and immunocompromise. Blood 1993;81:468-74.

33 Serrano M, Bellas C, Campo E, Ribera J, Martín C, Rubio $R$, et al. Hodgkin's disease in patients with antibodies to human immunodeficiency virus. Cancer 1990;65:2248-54.

34 Rubio R. Hodgkin's disease associated with human immunodeficiency virus infection. Cancer 1994;73:2400-7.

35 Moorthy RK, Thorley-Lawson DA. All three domains of the Epstein-Barr virus-encoded latent membrane protein LMP-1 are required for transformation of Rat-1 fibroblast. $\mathcal{f}$ Virol 1993;67:1638-46.

36 Khanna R, Burrows SR, Kurilla KG, Jacob CA, Misko IS, Sculley TB, et al. Localization of Epstein-Barr virus cytotoxic $T$ cell epitopes using recombinant vaccinia: implications for vaccine development. $\mathcal{F} \operatorname{Exp}$ Med 1992;176: 169-76.

37 Kadin ME. Hodgkin's disease: immunobiology and pathogenesis. In: Knowles DM, ed. Neoplastic hemathopathology. Baltimore: Williams and Wilkins, 1992:535-54. 